\title{
Eggplant (Solanum melongena L.): tissue culture, genetic transformation and use as an alternative model plant
}

\author{
Claudia Magioli ${ }^{1}$ and Elisabeth Mansur ${ }^{1,2}$
}

Received: March 12, 2003; Accepted: August 06, 2004

\begin{abstract}
RESUMO-(Berinjela (Solanum melongena L.): cultura de tecidos, transformação genética e uso como planta modelo). A berinjela é uma espécie solanácea não tuberosa de importância agronômica, cultivada principalmente por seus frutos. Na medicina popular, a berinjela é indicada para o tratamento de várias doenças, incluindo diabetes, artrite, asma e bronquite. A berinjela é suscetível a várias doenças e pragas que causam perdas econômicas significativas. Esse problema tem sido abordado com técnicas convencionais de melhoramento, utilizando espécies silvestres resistentes de Solanum, que possuem uma grande diversidade genética e são fontes de genes de interesse agronômico. A aplicação de metodologias in vitro à berinjela tem resultado em sucesso considerável. Os tecidos de berinjela apresentam um alto potencial morfogenético, sendo úteis para estudos de desenvolvimento e para o estabelecimento de abordagens biotecnológicas para a produção de variedades melhoradas, tais como o resgate de embriões, a seleção in vitro, a hibridização somática e a transformação genética. O conjunto dessas características também torna a berinjela um modelo completo para estudos em diferentes áreas de pesquisa, incluindo o controle da expressão gênica e a avaliação da estabilidade de somaclones derivados de diferentes processos morfogenéticos. Neste trabalho, são analisados fatores importantes que afetam a eficiência dos processos de regeneração in vitro por meio de organogênese e embriogênese, assim como de transformação genética, explorando ainda o potencial da espécie como planta modelo para o estudo de vários aspectos da genética e fisiologia vegetais.
\end{abstract}

Palavras-chave: Solanum melongena L., biotecnologia, cultura de tecidos, transformação genética, planta modelo

ABSTRACT -(Eggplant (Solanum melongena L.): tissue culture, genetic transformation and use as an alternative model plant). Eggplant is an agronomically important non-tuberous solanaceous crop grown primarily for its large oval fruit. In popular medicine, eggplant is indicated for the treatment of several diseases, including diabetes, arthritis, asthma and bronchitis. Eggplant is susceptible to a number of diseases and pests capable of causing serious crop losses. This problem has been addressed by hybridizing eggplant with wild resistant Solanum species, which present a wide genetic diversity and are source of useful agronomic traits. The application of in vitro methodologies to eggplant has resulted in considerable success. Eggplant tissues present a high morphogenetic potential that is useful for developmental studies as well as for establishing biotechnological approaches to produce improved varieties, such as embryo rescue, in vitro selection, somatic hybridization and genetic transformation. Taken together, these characteristics also make eggplant a complete model for studies on different areas of plant science, including control of gene expression and assessment of genetic stability of somaclones derived from different morphogenetic processes. In the present study, important factors that affect the efficiency of in vitro regeneration through organogenesis and embryogenesis as well as genetic transformation are analyzed. The potential of this species as a model plant for studying various aspects of plant genetics and physiology is also discussed.

Key words: Solanum melongena L., biotechnology, tissue culture, genetic transformation, model plant

\section{Introduction}

Eggplant (Solanum melongena L.; Division Anthophyta; Class Dicotyledoneae; Order Solanales) is an agronomically important non-tuberous solanaceous crop grown primarily for its large oval fruit. Eggplant is native to India and China and was probably introduced to Europe by Arabic traders and then brought to North America by early European settlers.

In popular medicine, eggplant is indicated for the treatment of several diseases, including diabetes, arthritis, asthma and bronchitis. In addition, several groups have provided evidence that eggplant extracts have a significant effect in reducing blood and liver cholesterol rates in humans (Khan 1979; Jorge et al. 1998) and adult rats (Silva et al. 1999). Nasunin, a major component of anthocyanin pigment of eggplant, has been shown to inhibit lipid peroxidation (Igarashi et al. 1993). More recently, free radical scavenging and iron chelating activities of nasunin were demonstrated by electron spin resonance (Noda et al. 1998; 2000). Furthermore, anti-mutagenic activity of pheophytin components from eggplant fruit extracts

\footnotetext{
1 Universidade do Estado do Rio de Janeiro, Instituto de Biologia Roberto Alcântara Gomes, Laboratório de Micropropagação e Transformação de Plantas, Rua São Francisco Xavier 524, PHLC/sala 505, Maracanã, CEP 20550-013, Rio de Janeiro, RJ, Brazil

2 Corresponding Author: mansur@uerj.br
} 
acting against several chemical mutagens was demonstrated by the Salmonella/microsome assay (Yoshikawa et al. 1996a; 1996b).

Eggplant is susceptible to several diseases and pests that cause serious crop losses. This problem has been addressed by hybridizing eggplant with wild resistant Solanum species, which present a wide genetic diversity and are source of useful agronomic traits. However, this approach is limited by sexual incompatibilities (Collonier et al. 2001) and difficulties in obtaining fertile progenies (Gleddie et al. 1986). In addition, traditional improvement methods may be hampered by the scarcity of natural resistance sources for some important diseases, impairing the obtention of resistant varieties (O'Brien 1983; Melo \& Costa 1985; Lin \& Xiao 1995). For example, no natural resistance sources are known for anthracnosis (Colletotrichum gloeosporioides), southern wilt (Ralstonia solanacearum) and the most common fungal disease of eggplant in Brazil, the Verticillium wilt (Verticillium dahliae).

The application of in vitro methodologies to eggplant has resulted in considerable success. Eggplant tissues present a high morphogenetic potential that is useful for developmental studies as well as for establishing biotechnological approaches to produce improved varieties, such as embryo rescue, in vitro selection, somatic hybridization and genetic transformation. Taken together, these characteristics also make eggplant a complete model for studies on different areas of plant science, including control of gene expression and assessment of genetic stability of somaclones derived from different morphogenetic processes.

Recent reviews on applications of biotechnology in eggplant have focused in aspects related to genetic resources and improvement of agronomic traits (Collonier et al. 2001; Kashyap et al. 2003). In the present review, important factors that affect the efficiency of in vitro regeneration through organogenesis and embryogenesis as well as genetic transformation are analyzed. The potential of this species as a model plant for studying various aspects of plant genetics and physiology is also discussed.

\section{Tissue culture}

Early studies of in vitro regeneration of eggplant were based on culturing cell suspensions (Fassuliotis et al. 1981; Gleddie et al. 1983), anthers (Isouard et al. 1979; Dumas de Vaulx \& Chambonnet 1982; Tuberosa et al. 1987) and protoplasts (Jia \& Potrykus 1981; Saxena et al. 1981; Bhatt \& Fassuliotis 1981; Guri \& Izhare 1984; Gleddie et al. 1986; Nishio et al. 1987; Li \& Zhang 1988; Clark et al. 1988). Successful development of morphogenic calli was obtained from isolated microspores, resulting in the production of putative spontaneously doubled haploids (Miyoshi 1996).

Several other protocols for plant regeneration via direct and indirect organogenesis have been developed from different eggplant tissues (Tab. 1). In those protocols, the regeneration efficiency has been reported to be affected by different factors, such as combination of growth regulators, explant type and genotype. Most of the organogenic systems reported are based on supplementing culture media with auxins and cytokinins, either alone (Kamat \& Rao 1978; Matsuoka \& Hinata 1979; Alicchio et al. 1982; Gleddie et al. 1983; Sharma \& Rajam 1995a) or in combination (Kamat \& Rao 1978; Matsuoka \& Hinata 1979; Sharma \& Rajam 1995a).

Different sources of explant have been used for the induction of organogenesis in eggplant, including hypocotyl (Kamat \& Rao 1978; Matsuoka \& Hinata 1979; Alicchio et al. 1982; Sharma \& Rajam 1995a; Magioli et al. 1998), leaf(Gleddie et al. 1983; Alicchio et al. 1982; Mukherjee et al. 1991; Sharma \& Rajam 1995a; Magioli et al. 1998), cotyledon (Alicchio et al. 1982; Sharma \& Rajam 1995a; Magioli et al. 1998), epicotyl (Magioli et al. 1998), stem nodes (Magioli et al. 1998) and roots (Franklin \& Sita 2003). The regeneration efficiencies reported in those systems were relatively low (approximately 7 shoots/explant) (Gleddie et al. 1983; Mukherjee et al. 1991; Sharma \& Rajam 1995a), except in the one described by Sharma \& Rajam (1995a), who achieved the production of 20 shoots/explant in one of the four cultivars studied. The use of low concentrations (100-200nM) of thidiazuron (TDZ) was also reported to induce efficient organogenesis in five cultivars (around 20 shoots/ explant) from leaf and cotyledon explants (Magioli et al. 1998; 2000). The effect of different sugars and osmotic conditions has been studied and highest regeneration rates were observed in media with low sucrose concentrations (11 and $22 \mathrm{mM}$ ) during shoot development. However, the normal concentration of sucrose used Murashige and Skoog (MS) medium $(88 \mathrm{mM})$ induced more efficient root development (Mukherjee et al. 1991).

Protocols for inducing somatic embryogenesis from eggplant tissues have also been described, using 
Table 1. In vitro regeneration studies of eggplant (Solanum melogena L.).

\begin{tabular}{|c|c|c|c|}
\hline Mechanism & Explant & Growth regulators $(\mu \mathrm{M})$ & Reference \\
\hline Organogenesis & $\begin{array}{l}\text { Hypocotyl } \\
\text { Hypocotyl } \\
\text { Hypocotyl, cotyledon and leaf } \\
\text { Leaf } \\
\text { Leaf } \\
\text { Hypocotyl, cotyledon and leaf } \\
\text { Epicotyl, hypocotyl, cotyledon, leaf and node } \\
\text { Root }\end{array}$ & $\begin{array}{l}\text { 5.7 IAA }+4.4 \text { BAP } \\
\text { 1 BAP alone or with } 0.09 \mathrm{NAA} \\
\text { 1.8 2.4-D } \\
44.4 \mathrm{BAP} \\
\text { 9.3 KIN } \\
11.1 \mathrm{BAP}+2.92 .4-\mathrm{D} \\
0.2 \mathrm{TDZ} \\
0.5 \mathrm{TDZ}+13.3 \mathrm{BAP}\end{array}$ & $\begin{array}{l}\text { Kamat \& Rao } 1978 \\
\text { Matsuoka \& Hinata } 1979 \\
\text { Alicchio et al. } 1982 \\
\text { Gleddie } \text { et al. } 1983 \\
\text { Mukherjee } \text { et al. } 1991 \\
\text { Sharma \& Rajam } 1995 \text { a } \\
\text { Magioli et al. } 1998 \\
\text { Franklin \& Sita } 2003\end{array}$ \\
\hline Embryogenesis & $\begin{array}{l}\text { Zygotic embryos } \\
\text { Hypocotyl } \\
\text { Cell suspension culture and leaf } \\
\text { Cotyledon } \\
\text { Leaf and cotyledon } \\
\text { Hypocotyl } \\
\text { Leaf } \\
\text { Leaf and cotyledon } \\
\text { Hypocotyl, cotyledon and leaf } \\
\text { Leaf and cotyledon }\end{array}$ & $\begin{array}{l}\text { 5.4 NAA } \\
43 \mathrm{NAA} \\
54 \mathrm{NAA} \\
27 \mathrm{NAA} \\
5.4 \mathrm{NAA} \\
2.7-10.8 \mathrm{NAA} \\
43 \mathrm{NAA}+0.5 \mathrm{KIN} \\
502.4-\mathrm{D} \\
5.7-54 \mathrm{NAA} \\
54 \mathrm{NAA}\end{array}$ & $\begin{array}{l}\text { Yamada et al. } 1967 \\
\text { Matsuoka \& Hinata } 1979 \\
\text { Gleddie et al. } 1983 \\
\text { Fobert \& Webb } 1988 \\
\text { Fillippone \& Lurquin } 1989 \\
\text { Ali et al. } 1991 \\
\text { Rao \& Singh } 1991 \\
\text { Saito \& Nishimura } 1994 \\
\text { Sharma \& Rajam 1995a } \\
\text { Magioli et al. } 2001\end{array}$ \\
\hline
\end{tabular}

IAA - indole-3-acetic acid; BAP - 6-benzylaminopurine; NAA - $\alpha$-naphthaleneacetic acid; 2.4-D - 2.4-dichlorophenoxyacetic acid; KIN kinetin; TDZ - thidiazuron.

different growth regulators and explant types (Tab. 1). The first report was published by Yamada et al. (1967), who induced somatic embryogenesis from zygotic embryos cultured on MS supplemented with indole-3acetic acid (IAA). Similarly to the observed in the organogenic process, the efficiency of somatic embryogenesis depends on several factors, including genotype, explant type and growth regulators. In general, high frequencies of somatic embryogenesis induction are obtained in response to the auxins $\alpha$-naphthaleneacetic acid (NAA) and 2,4dichlorophenoxyacetic acid (2,4-D) (Matsuoka \& Hinata 1979; Gleddie et al. 1983; Ali et al. 1991; Saito \& Nishimura, 1994; Magioli et al. 2001a). However, conversion of somatic embryos into plantlets is usually limited due to abnormalities such as hyperdricity, lack of apical meristem, cotyledon fusion and inefficient maturation (Gleddie et al. 1983; Saito \& Nishimura 1994; Magioli et al. 2001a). Nevertheless, conversion rates can reach up to $92 \%$ by culturing mature embryos MS solidified with 1\% phytagel (Saito \& Nishimura 1994; Magioli et al. 2001a). A review on somatic embryogenesis in eggplant focusing on the factors that affect the process as well as its practical applications was recently published by Kantharajah \& Golegaonkar (2004).

Studies on the morphological aspects of somatic embryogenesis have been performed in a number of species and showed that somatic embryos can have different origins according to the species and the explant type. For example, in geranium and tomato somatic embryos are formed from the epidermal cells of hypocotyl explants (Hutchinson et al. 1996; Newman et al. 1996). In peanut, embryos can be formed from meristematic cells of calli derived from cotyledons, from parenchymatic cells of young leaves or from meristematic and submeristematic cells of apical meristems (Sagare et al. 1995). In eggplant, somatic embryos induced by NAA are formed from perivascular parenchymatic cells originating indeterminate meristematic masses, which can either give rise to adventitious roots or pro-embryogenic masses (Tarré et al. 2004).

The type and concentration of a given growth regulator in association to specific genotypes can cause significant differences in the morphogenetic responses of eggplant. For example, Kamat \& Rao (1978) using hypotocyl explants induced only the development of rhizogenic calli in the presence of NAA and anaphthoxyacetic acid (NOA), while regeneration through organogenesis was obtained in the presence of IAA. Both organogenesis and embryogenesis were observed by Matsuoka \& Hinata (1979), in response to different NAA concentrations using the same explant type. Following that study, Matsuoka (1983) screened the effect of different concentrations of NAA 
$(21.5-108 \mu \mathrm{M})$ in somatic embryogenesis and obtained best results in the presence of $37.8-48.6 \mu \mathrm{M}$. Gleddie et al. (1983) induced somatic embryogenesis from leaf explants and cell suspension cultures of cultivar Imperial Black Beauty in the presence of $54 \mu \mathrm{M} N A A$, whereas Fillippone \& Lurquin (1989) had obtained best results with leaf and coyledon explants of cultivar Violetta Lunga di Napoli in the presence of a much lower concentration $(5.4 \mu \mathrm{M})$ of the same growth regulator. Mariani (1992) also reported somatic embryogenesis in response to $54 \mu \mathrm{M}$ NAA using seedlings of cultivar Giulietta germinated in the dark. Fobert \& Webb (1988) observed a correlation between the development of adventitious roots and somatic embryos in cotyledons from cultivar Imperial Black Beauty, in response to different NAA concentrations. Rhizogenesis was induced in low concentrations $(0.5-2.7 \mu \mathrm{M})$, while intermediate levels favored somatic embryogenesis $(5.4-27 \mu \mathrm{M})$ and higher concentrations (54-270 $\mu \mathrm{M})$ mainly induced callogenesis. Similar results were obtained with the Brazilian variety F-100 (C.S. Magioli, dados não publicados). On the other hand, Rao \& Singh (1991) cultivated leaf explants in medium supplemented with 0.5 and $10.8 \mu \mathrm{M}$ NAA and failed to induce embryogenesis with the same concentrations. In their report, embryogenic calli were obtained in the presence of higher NAA concentrations $(27$ and $64 \mu \mathrm{M})$, although best results were achieved when NAA was combined with $0.5 \mathrm{mM}$ Kinetin (KIN). Higher embryogenesis rates in cotyledons cultured in the presence of $50 \mu \mathrm{M} 2,4-\mathrm{D}$ were obtained by Saito $\&$ Nishimura (1994), as compared to $54 \mu \mathrm{M}$ NAA. Ali et al. (1991) also observed embryogenesis in hypocotyl explants from variety Insanum in the presence of low concentrations of 2,4-D (2.3-9.0 $\mu \mathrm{M})$. In contrast, Alicchio et al. (1982) reported the occurrence of organogenesis in response to low concentrations of the same auxin. High induction frequencies of somatic embryogenesis were obtained from leaf and cotyledon explants of the Brazilian variety F-100 in the presence of $54 \mu \mathrm{M}$ of NAA, whereas $2,4-\mathrm{D}$ in different concentrations failed to induce embryo development (Magioli et al. 2001a). The occurrence of both somatic embryos and shoot primordia has been reported to occur in the same callus after prolonged culture in the

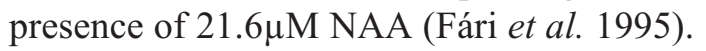

In recent years, there has been increasing awareness of bactericidal antibiotics stimulating or inhibiting the regenerative potential of explants, depending on each specific combination between a given antibiotic and plant species. The presence of cefotaxime, ampicillin or vancomycin did not affect embryogenic callus formation and development from leaf and cotyledon explants of eggplant. However, antibiotic treatment reduced the number of embryos produced per callus by $52 \%$ (cefotaxime and amplicillin) and 37\% (vancomycin) (Magioli et al. 2001a). Cefotaxime was found to enhance callus fresh weight, but also causing a decrease on the rate of embryo regeneration, whereas timentin showed no effect on embryo differentiation (Picoli et al. 2001).

In vitro regeneration systems have been used as strategies to select valuable agronomic traits in eggplant. Several useful traits from wild species such as resistance to nematodes and atrazin have been found in somatic hybrids obtained from protoplast fusion (Gleddie et al. 1985; Guri \& Sink 1988a; Collonier et al. 2001). Dihaploid plants were produced through anther culture of somatic hybrids between eggplant and S. awthiopicum gilo, with the objective of obtaining Fusarium resistance (Rizza et al. 2002). Specific applications of anther culture and somatic hybridization in breeding programs for eggplant improvement were recently reviewed (Collonier et al. 2001; Kashyap et al. 2003).

Somaclonal variation is also a possible means of obtaining variation for plant breeding, although studies on somaclonal variants with useful traits are limited. In eggplant, somaclonal variants were observed by Rotino et al. (1991) and callus lines resistant to culture filtrate of Verticillium were reported by Rotino et al. (1987) and Alicchio (1990). Selection of atrazine resistance was achieved by using mutagenized organogenic explants (Farooqui et al. 1997). In addition, the frequency and inheritance of somaclonal variations related to morphological characters and pollen fertility among plants derived from somatic embryos induced by 2,4 D or NAA were analysed by Hitomi et al. (1998).

\section{Genetic transformation via Agrobacterium}

Genetic transformation of eggplant via Agrobacterium was first reported by Guri \& Sink (1988b), using leaf explants and a cointegrate vector, although no success was achieved with a binary vector. Later, Fillipone \& Lurquin (1989) reported the transformation of leaf and cotyledon explants using the wild supervirulent strain A281. Transgenic plants were obtained by Rotino \& Gleddie (1990) and Fári et al. (1995), using organogenic regeneration systems. An optimization of factors that influence transformation 
efficiency, including length of pre and post-coculture periods, explant type, and genotype was performed using a TDZ-based organogenic system (Magioli et al. 2000). The efficiency of transformation protocols based on organogenesis may be influenced by the antibiotic used to eliminate $A$. tumefaciens. For example, augmentin can cause enhanced shoot proliferation induced by TDZ (Billings et al. 1997). Recently, an organogenic system from root explants was applied in a protocol for transformation of variety MEBH 11. These explants demonstrated a high susceptibility to Agrobacterium and quick regeneration capacity on selection media, resulting in $82.5 \%$ of transgenic calli induction with a means of 24 transgenic shoots per callus (Franklin \& Sita 2003).

The production of transgenic eggplant through somatic embryogenesis either fails to occur (Fillipone \& Lurquin 1989) or is achieved with very low efficiency (Fári et al. 1995). It has been demonstrated that both cocultivation with Agrobacterium and the presence of bactericidal antibiotics used in transformation protocols cause a reduction of $80-99 \%$ in the number of embryo/explant. The inhibitory effect on somatic embryos development may result from the interaction between the physiological alterations caused by these treatments and the delicate processes of gene regulation that are induced in early culture stages (Magioli et al. 2001a).

Following the establishment of basic protocols, successful introduction of agronomic traits into eggplant was achieved (Tab. 2). Resistance to Colorado Potato Beetle (Leptinotarsa decemlineata Say) (CPB), a pest that has developed resistance to synthetic insecticides and became a serious problem for agriculture in Europe and America (Arpaia et al. 1997), has been pursued by a number of groups. Chen et al. (1995) have produced transgenic eggplant lines with the introduction of Bacillus thuringiensis $(B t)$ genes, but resistance to $\mathrm{CPB}$ was not observed. Later, different groups obtained lines resistant to CPB by using mutagenized versions of cryIIB (Arpaia et al. 1997; Iannacone et al. 1997) and a synthetic version of cryIIIA Bt genes (Jelencovic et al. 1998). Field trials demonstrated high levels of resistance in transgenic plants produced after the introduction of a mutagenized Bt cryIIIB gene, without detrimental effects on nontarget arthropods (Acciarri et al. 2000). These resistant transgenic eggplants can potentially be used for the development of new varieties.

Besides CPB resistance, there are other examples of genetic improvement of eggplant via
A. tumefaciens. Resistance to Leucinodes orbanalis was obtained in transgenic plants harboring the $B t$ $(C r y 1 A b)$ gene. Tolerance against osmotic stress induced by salt drought and chilling stress was achieved in transformants expressing the bacterial mannitol-1phosphodehydrogenase $(m t l D)$ gene (Prabhavathi et al. 2002) and transgenic hybrids harboring the parthenocarpic gene DefH9-iaaM presented a significant yield increment that resulted in a $10 \%$ reduction in cultivation costs (Donzella et al. 2000).

\section{Eggplant as a model plant}

In addition to providing tools for selection of valuable agronomic traits, in vitro culture systems can be used as models to study molecular signals in plant physiology and development. The establishment of efficient in vitro regeneration systems is also the first step for developing genetic transformation protocols in order to introduce novel traits or to study regulation of gene expression in plants. The availability of efficient protocols for in vitro regeneration, both via organogenesis and embryogenesis, as well as for genetic transformation of eggplant, offers an excellent model system to investigate plant physiology in vitro. Accordingly, reports published in the last few years provided several examples for the use of eggplant as a model plant and will be discussed herein.

Different plant in vitro morphogenic systems have been used to study the role of polyamines (PA), which are proposed as a new class of growth regulators involved in differentiation, reproduction, disease resistance and stress (Scoccianti et al. 2000). Eggplant tissues may favour a clearer picture of these molecular signals in differentiation processes, considering their ability to regenerate plants in vitro through different morphogenetic processes. The effect of polyamines in the process of in vitro morphogenesis has been studied in eggplant by analyzing cellular levels of free and conjugated polyamines and the activity of enzymes involved in biosynthesis and oxidation of polyamines or by treating explants with exogenous polyamines and inhibitors of synthesis of polyamines.

The effect of polyamines, polyamine precursors and biosynthetic inhibitors during embryogenesis was reported by Fobert \& Webb (1988). A relationship between the spatial distribution of free and conjugated endogenous polyamine and the differential morphogenetic potential within explants have been observed during embryogenesis (Yadav \& Rajam 1997) and organogenesis (Scoccianti et al. 2000). 
Table 2. Genetic transformation of eggplant (Solanum melogena L.) via Agrobacterium.

\begin{tabular}{|c|c|c|c|}
\hline Explant & Gene & Observations & Reference \\
\hline Leaf & NptII & $\begin{array}{l}\text { Success with a binary vector, no information about } \\
\text { transformation efficiency }\end{array}$ & Guri \& Sink 1988 \\
\hline Cotyledon / Leaf & NptII & $\begin{array}{l}\text { Stable transformation using the wild supervirulent } \\
\text { strain A281 }\end{array}$ & Filippone \& Lurquin 1989 \\
\hline Leaf & NptII and $C A T$ & Transformation efficiency of $7,6 \%$ & Rotino \& Gleddie 1990 \\
\hline Cotyledon & $N p t I I$ and $G U S$ & $10 \%$ of transgenic organogenic calli regenerated plants & Fari et al. 1995 \\
\hline Hypocotyl & Bt (cry IIIB) & Resistance to CPB was not observed & Chen et al. 1995 \\
\hline Hypocotyl & $B t(\operatorname{cry} I I I B)$ & $\begin{array}{l}\text { Resistance to CPB using a mutagenized version of the } \\
\text { Bt cryIIIB gene }\end{array}$ & Arpaia et al. 1997 \\
\hline Cotyledon & Bt (cry IIIB) & $\begin{array}{l}\text { Resistance to CPB using a mutagenized version of the } \\
\text { Bt cryIIIB gene }\end{array}$ & Iannacone et al. 1997 \\
\hline Leaf & $\begin{array}{l}\text { Bt (cry IIIB) and } \\
\text { NptII and GUS }\end{array}$ & $\begin{array}{l}\text { Influence of growth regulators and antibiotics on } \\
\text { transformation efficiency }\end{array}$ & Billings et al. 1997 \\
\hline Leaf & $\begin{array}{l}\text { Bt (cry IIIA) and } \\
\text { GUS }\end{array}$ & $\begin{array}{l}\text { Resistance to CPB using a synthetic version of the } \\
\text { Bt cryIIIA gene }\end{array}$ & Jelenkovic et al. 1998 \\
\hline Cotyledon & Bt $($ Cry $1 A b)$ & $\begin{array}{l}\text { Resistance to Leucinodes orbonalis using a synthetic } \\
\text { crylAb gene }\end{array}$ & Kumar et al. 1998 \\
\hline Leaf & Luc & Evaluation of the stability of luciferase gene expression & Hanyu et al. 1999 \\
\hline Cotyledon & $\begin{array}{l}\text { pAtgtrp-5::GUS } \\
\text { and NptII }\end{array}$ & $\begin{array}{l}\text { Optimization of factors which influence transformation } \\
\text { efficiency }\end{array}$ & Magioli et al. 2000 \\
\hline Cotyledon & DefH9-iaaM & Parthenocarpic transgenic plants & Donzella et al. 2000 \\
\hline Cotyledon & $M t l D$ & Tolerance against osmotic stress & Prabhavathi et al. 2002 \\
\hline Root & NptII and GUS-INT & Stable transformation using root explants & Franklin \& Sita 2003 \\
\hline
\end{tabular}

NptII - neomycin phosphotransferase II, CAT - chloramphenicol acetyltransferase, Bt (cry IIIB) - Bacillus thuringiensis cry IIIB; Bt (cry IIIA) - Bacillus thuringiensis cry IIIA; Bt (Cry 1Ab) - Bacillus thuringiensis cry IAb; GUS - $\beta$-glucuronidase; Luc - luciferase; pAtgrp-5 - regulatory region of the Arabidopsis thaliana glycine rich protein 5; DefH9-iaaM - regulatory region of the DEFICIENS 9 gene from snapdragon and the auxin-synthesizing gene coding region (IaaM) from Pseudomonas syringae pv savastanoi; MtlD - bacterial mannitol-1-phosphodehydrogenase gene.

Putrescine has been positively correlated to the efficiency of somatic embryogenesis and shown to occur in different levels during the process, while spermine and spermidine showed no significant effect (Sharma \& Rajam 1995b; Yadav \& Rajam 1997; 1998). In hypocotyl segments, high levels of conjugated spermidine along with high levels of total PA could be correlated with the formation of somatic embryos (Sharma \& Rajam 1995b). Studies using root cultures of eggplant demonstrated that PAs, particularly spermidine, are intricately involved in root growth and differentiation of lateral roots (Sharma et al. 1997).

The accumulation of BiP (Binding Protein), an endoplasmic reticulum resident, stress-related protein of the Heat shock protein (Hsp) 70 family, was demonstrated in hyperhidric plants originated from an organogenic system of eggplant. This finding supports the assumption that the monitoration of BiP synthesis can be used to detect intracellular stress in plants (Picoli et al. 2001). Eggplant was also used as model plant for the study the expression and the incorporation of the luciferase gene (luc) and LUC activity in a longterm period. The expression of the $l u c$ gene was found to be stable and its specific activity was shown to fluctuate in response to environmental conditions (Hanyu et al. 1999).

Somatic embryogenesis systems in eggplant are also good models to study the earliest stages of embryo development. Specific alterations in gene expression during early stages of somatic embryogenesis induced by 2,4-D have been described through differential display of RNA species by Momiyama et al. (1995) and Afele et al. (1996), with the identification of three classes of genes that were newly expressed or showed enhanced expression during the first 10 days of culture. Differential cultivar responses to the induction of somatic embryogenesis were correlated to differences in gene expression patterns (Afele et al. 1996). In addition, an antioncogen homolog and the activation of retrotransposon were described during the early phase of somatic embryogenesis (Momiyama et al. 1996). Differential display and Restriction Fragment Length Polymorphism (RFLP) analyses were used to study 
alterations in DNA methylation and gene expression in cell suspension cultures which produced either somatic embryos or shoots, resulting in the identification of one organogenesis and two somatic embryogenesis related transcripts (Bucherna et al. 2001).

The expression pattern of Atgrp-5 gene (glycinrich protein isolated from Arabidopsis thaliana) in transgenic eggplants harboring a construct containing an Atgrp-5 promoter-GUS fusion showed to be highly regulated during developmental processes and to have preferential expression in epidermis and stem phloem (Magioli et al. 2000), confirming the observations on tobacco and Arabidopsis (Sachetto-Martins et al. 1995). One important aspect of this work was that embryogenesis in eggplant could be efficiently induced from leaves of in vitro transgenic plants. In contrast, induction of somatic embryogenesis in Arabidopsis is based on the use of immature zygotic embryos, involving difficult and time-consuming procedures.

Considering that epidermis and stem phloem are sites for pathogen penetration and diffusion, Atgrp promotor has potential biotechnological interest and may be used in programs aiming at the genetic improvement of eggplant by introducing genes which confer resistance to diseases or pests. In addition, the analysis of GUS expression during the early stages of somatic embryogenesis using the embryogenic system established by Magioli et al. (1998) demonstrated that this promoter is activated simultaneously with the first anatomical events leading to embryo development, indicating that Atgrp-5 may participate in the early cellular events necessary for entering an embryogenic program (Magioli et al. 2001b).

In conclusion, eggplant provides a unique system to study morphogenesis and somaclonal variation, taking into account that in vitro regeneration can be induced from different explants, by distinct growth regulators and morphogenetic pathways. In addition, the availability of efficient transformation protocols favors gene regulation studies, especially those related to embryogenesis, with advantages over other species. From this perspective, eggplant can be considered as an alternative model plant to study different aspects of plant biology.

\section{References}

Acciarri, N.; Vitelli, G.; Arpaia, S.; Mennella, G.; Sunseri, F. \& Rotino, G.L. 2000. Transgenic resistance to the Colorado potato beetle in Bt-expressing eggplant fields. Hortscience 35(4): 722-725.
Afele, J.C.; Tabei, Y.; Yamada, T.; Momiyama, T.; Takaiwa, F.; Kayano, T.; Nishimura, S. \& Nishio, T. 1996. Identification of mRNAs differentially expressed between embryogenic and non-embryogenic cultivars of eggplant during somatic embryogenesis. Japan Agricultural Research Quarterly 30(3): 175-179.

Ali, M.; Okubo, H. \& Fujieda, K. 1991. In vitro multiplication of intraspecific and interspecific Solanum hybrids through somatic embryogenesis and adventitious organogenesis. Journal of the Japanese Society for Horticultural Science 60(3): 601-612.

Alicchio, R. 1990. Somaclonal variation in eggplant (Solanum melongena L.). Biotechnology in Agriculture and Forestry 11: 416-433.

Alicchio, R.; Del Grosso, E. \& Boschueri, E. 1982. Tissue cultures and plant regeneration from different explants in six cultivars of Solanum melongena. Experientia 38: 449-450.

Arpaia, S.; Mennella, G.; Onofaro, V. \& Perri, E. 1997. Production of transgenic eggplant (Solanum melongena L.) resistant to Colorado Potato Beetle (Leptinotarsa decemlineata Say). Theoretical and Applied Genetics 95: 329-334.

Bhatt, D.P. \& Fassuliotis, G. 1981. Plant regeneration from mesophyll protoplasts of eggplant. Zeitschrift fur Pflanzenphysiologie 104: 481-489.

Billings, S.; Jelenkovic, G.; Chin, C-K. \& Eberhadt, J. 1997. The effect of growth regulation and antibiotics on eggplant transformation. Journal of the American Society for Horticultural Science 122: 158-162.

Bucherna, N.; Szabo, E.; Heszky, L. E. \& Nagy, I. 2001. DNA methylation and gene expression differences during alternative in vitro morphogenetic processes in eggplant (Solanum melongena L.). In Vitro Cellular \& Developmental Biology-Plant 37(5): 672-677.

Chen, Q.; Jelenkovic, G.; Chin, C.; Billings, S.; Eberhardt, J. \& Goffreda, J.C. 1995. Transfer and transcriptional expression of coleopteran CryIIIB endotoxin gene of Bacillus thuringiensis in eggplant. Journal of the American Society for Horticultural Science 120: 921-927.

Clark, C.B.; Sihachakr, D.; Haicour, R.; Serraf, E.; Barrientos, E.; Herbreteau, C.; Ducreux, G.; Rossignol, L. \& Souvannavong, V. 1988. Electrofusion for the production of somatic hybrid plants of Solanum melongena L. and Solanum khasianum. Plant Science 57(3): 215-224.

Collonier, C.; Fock, I.; Kashyap, V.; Rotino, G.L.; Daunay, M.C.; Lian., Y.; Mariska, I.K.; Rajam, M.V.; Servaes, A.; Ducreux, G. \& Sihachakr, D. 2001. Applications of biotechnology in eggplant. Plant Cell, Tissue and Organ Culture 65: 91-107.

Donzella, G.; Spena, A. \& Rotino, G.L. 2000. Transgenic parthenocarpic eggplants: superior germplasm for increased winter production. Molecular Breeding 6(1): 79-86.

Dumas de Vaulx, R. \& Chambonnet, D. 1982. Culture in vitro d'anthères d'aubergine Solanum melongena L.): stimulation de la production de plantes au moyen de traitements à $+35^{\circ} \mathrm{C}$ associés à de faibles teneurs en substances de croissance. Agronomie 2: 983-988. 
Fári, M.; Nagy, I.; Csányi, M.; Mitykó, J. \& Andrásfalvy, A. 1995. Agrobacterium mediated genetic transformation and plant regeneration via organogenesis and somatic embryogenesis from cotyledon leaves in eggplant (Solanum melongena L. cv. 'Kecskemeti lila'). Plant Cell Reports 15: 82-86.

Farooqui, M.A.; Rao, A.V.; Jayasree, T. \& Sadanandam, A. 1997. Induction of atrazine resistance and somatic embryogenesis in Solanum melongena. Theoretical and Applied Genetics 95(4): 702-705.

Fassuliotis, G.; Nelson, B.V. \& Bhatt, D.P. 1981. Organogenesis in tissue culture of Solanum melongena cv. Florida Market. Plant Science Letters 22: $119-125$.

Fillipone, E. \& Lurquin, P.F. 1989. Stable transformation of eggplant (Sollanum melongena L.) by cocultivation of tissues with Agrobacterium tumefaciens carrying a binary plasmid vector. Plant Cell Reports 8: 370-373.

Fobert, P.R. \& Webb, D.T. 1988. Effects of polyamines, polyamine precursors, and polyamine biosynthetic inhibitors on somatic embryogenesis from eggplant (Solanum melongena) cotyledons. Canadian Journal of Botany 66(9): 1734-1742.

Franklin, G. \& Lakshmi Sita, G. 2003. Agrobacterium tumefaciens-mediated transformation of eggplant (Solanum melongena L.) using root explants. Plant Cell Reports 21: 549-554.

Gleddie, S.; Fassuliotis, G.; Keller, W. \& Setterfield, G. 1985. Somatic hybridization as a potential method of transferring nematode and mite resistance into eggplant. Zeitschrift fur Pflanzenzuchtung 94: 352-355.

Gleddie, S.; Keller, W. \& Setterfield, G. 1983. Somatic embryogenesis and plant regeneration from leaf explants and cell suspensions of Solanum melongena (eggplant). Canadian Journal of Botany 61: 656-666.

Gleddie, S.; Keller, W. \& Setterfield, G. 1986. Somatic embryogenesis and plant regeneration from cell suspension derived protoplasts of Solanum melongena (eggplant). Canadian Journal of Botany 64: 355-361.

Guri, A. \& Izhare, S. 1984. Improved efficiency of plant regeneration from protoplasts of eggplant (Solanum melongena L.). Plant Cell Reports 3: 247-249.

Guri, A. \& Sink, K.C. 1988a. Organelle composition in somatic hybrid plants between eggplant (Solanum melongena) and Solanum torvum. Theoretical and Applied Genetics 76: 490-496.

Guri, A. \& Sink, K.C. 1988b. Agrobacterium transformation of eggplant. Journal of Plant Physiology 133: 52-55.

Hanyu, H; Murata, A.; Park, E.Y.; Okabe, M.; Billings, S.; Jelenkovic, G.; Pedersen, H. \& Chin, C-K. 1999. Stability of luciferase gene expression in a long term period in transgenic eggplant, Solanum melongena. Plant Biotechnology 16(5): 403-407.

Hitomi, A.; Amagai H. \& Ezura, H. 1998. The influence of auxin type on the array of somaclonal variants generated from somatic embryogenesis of eggplant, Solanum melongena L. Plant Breeding 117: 379-383.
Hutchinson, M.J.; Krishnaraj, S. \& Saxena, P.K. 1996. Morphological and physiological changes during thidiazuron-induced somatic embryogenesis in geranium (Pelargonium $x$ Hortorum bailey) hypocotyl cultures. International Journal of Plant Science 157: 440-446.

Iannacone, R.; Grieco, D. \& Cellini, F. 1997. Specific sequence modifications of a cry3B endotoxin gene result in high levels of expression and insect resistance. Plant Molecular Biology 34: 485-496.

Igarashi K.; Yoshida, T. \& Suzuki, E. 1993. Antioxidative activity of nasunin in chouja-nasu (little eggplant, Solanum melongena L. Chouja). Journal of the Japanese Society of Food Science and Tecnology 40(2): 138-143.

Isouard, G.; Raquin, C. \& Demarly, Y. 1979. Obtention de plantes haploides et diploides par culture in vitro d'anthères d'aubergine (Solanum melongena L.). Comptes Rendus de l' Academie de Sciences de Paris 288: 987-989.

Jelenkovic, G.; Billings, S.; Chen, Q.; Lashomb, J.; Hamilton, G. \& Ghidiu, G. 1998. Transformation of eggplant with synthetic cryIIIA gene produces a high level of resistance to the Colorado potato beetle. Journal of the American Society for Horticultural Science 123: 19-25.

Jia, J. \& Potrykus, I. 1981. Mesophyll protoplasts from Solanum melongena var. depressum Bailey regenerate to fertile plants. Plant Cell Reports 1: 71-72.

Jorge, P.A.R.; Neyra, L.C.; Osaki, R.M.; Almeida, E. \& Bragagnolo, N. 1998. Efeito da berinjela sobre os lípides plasmáticos, a peroxidação lipídica e a reversão da disfunção endotelial na hipercolesteromia experimental. Arquivos Brasileiros de Cardiologia 70(2): 87-91.

Kamat, M.G. \& Rao, T.S. 1978. Vegetative multiplication of eggplants (Solanum melongena) using tissue culture techniques. Plant Science Letters 13: 57-65.

Kantharajah, A.S. \& Golegaonkar, P.G. 2004. Somatic embryogenesis in eggplant. Scientia Horticulturae 99: 107-117.

Kashyap, V.; Kumar, S.V.; Collonnier, C.; Fusari, F.; Haicour, R.; Rotino, G.L.; Sihachakr, D. \& Rajam, M.V. 2003. Biotechnology of eggplant. Scientia Horticulturae 97: $1-25$.

Khan, R. 1979. Solanum melongena and its ancestral forms. Pp. 629-636. J. Hawkes; R. Lester \& A. Skelding (eds.). In: The Biology and Taxonomy of the Solanaceae.

Kumar, P.A.; Mandaokar, A.; Sreenivasu, K.; Chakrabarti, S.K.; Bisaria, S.; Sharma, S.R.; Kaur, S. \& Sharma, R.P. 1998. Insect-resistant transgenic brinjal plants. Molecular Breeding 4(1): 33-37.

Li, G. \& Zhang, L. 1988. Regeneration of fertile plants from cotyledon protoplasts in Solanum melongena. Acta Genetica Sinica 15(3): 181-184.

Lin, B. \& Xiao, Y. 1995. Sources of resistance to Verticillium wilt in Solanum melongena and its affinities identified by improved root dip method. Capsicum Newsletter 14: 81-84.

Magioli, C.; Barrôco, R.M.; Rocha, C.A.B.; SantiagoFernandes, L.D.; Mansur, E.; Engler, G.; Margis-Pinheiro, M. \& Sachetto-Martins, G. 2001b. Somatic embryo formation in Arabidopsis and eggplant is associated with expression of a glycine-rich protein gene (Atgrp5). Plant Science 161: 559-567. 
Magioli, C.; Rocha, A.P.M.; Margis-Pinheiro, M.; SachettoMartins, G. \& Mansur, E. 2000. Establishment of an efficient Agrobacterium-mediated transformation system for eggplant and study of a potential biotechnologically useful promoter. Journal of Plant Biotechnology 2(1): 43-49.

Magioli, C.; Rocha, A.P.M.; Tarré, E.; Santiago-Fernandes, L.D.; Oliveira, D.E.; Krul, W.R. \& Mansur, E. 2001a. Effect of morphological factors, antibiotics and Agrobacterium co-cultivation in the efficiency of somatic embryogenesis of eggplant (Solanum melongena L.). Journal of Plant Biotechnology 3(1): 19-25.

Magioli, C.; Rocha, A.P.M.; Oliveira, D.E. \& Mansur, E. 1998. Efficient shoot organogenesis of eggplant (Solanum melongena L.) induced by thidiazuron. Plant Cell Reports 17: 661-663.

Mariani, P. 1992. Eggplant somatic embryogenesis combined with synthetic seed technology. Capsicum Newsletter 289-294 (special issue).

Matsuoka, H. \& Hinata, K. 1979. NAA- induced organogenesis and embryogenesis in hipocotyl callus of Solanum melongena L. Journal of Experimental Botany 30: 363-370.

Melo, I.S. \& Costa, C.P. 1985. Inheritance of resistance to Verticillium wilt in Solanum melongena. Revista Brasileira de Genética 3(4): 759-763.

Miyoshi, K. 1996. Callus induction and plantlet formation through culture of isolated microspores of eggplant (Solanum melongena L.) Plant Cell Reports 15: 391-395.

Momiyama, T.; Afele, J.C.; Saito, T.; Kayano, T.; Tabei, Y.; Takaiwa, K.; Takayanagi, K. \& Nishimura, S. 1995. Differential display identifies developmentally regulated genes during somatic embryogenesis in eggplant (Solanum melongena L.). Biochemistry and Biophysical Research Communications 213(2): 376-382.

Momiyama, T.; Kayano, T.; Afele, J.C.; Tabel, Y.; Nishimura, S.; Takaiwa, F.; Nishio, T. \& Takayanagi, K. 1996. Increased expression of antioncogene homolog and activation of retrotransposon during early phase of somatic embryonenesis in eggplant. Plant Physiology 111(2): 636-636.

Mukherjee, S.K.; Rathinasabapathi, B. \& Gupta, N. 1991. Low sugar and osmotic requirements for shoot regeneration from leaf pieces of Solanum melongena L. Plant Cell, Tissue and Organ Culture 25: 13-16.

Newman, P.O.; Krishnaraj, S. \& Saxena, P.K. 1996. Regeneration of tomato (Lycopersicon esculentum Mill.): somatic embryogenesys and shoot organogenesis from hypocotyl explants induced with 6-benzyladenine. International Journal of Plant Science 157(5): 554-560.

Nishio, T.; Sato, T. \& Takayanagi, K. 1987. Efficient eggplant regeneration from hypocotyl protoplasts in eggplant Solanum melongena L. nd Solanum incanum L. Japanese Journal of Breeding 37: 389-396.

Noda, Y.; Kneyuki, T.; Igarashi, K.; Mori, A. \& Packer, L. 1998. Antioxidant activity of nasunin, an anthocyanin in eggplant. Research Communications in Molecular Pathology and Pharmacology 102(2): 175-187.
Noda, Y.; Kneyuki, T.; Igarashi, K.; Mori, A. \& Packer, L. 2000. Antioxidant activity of nasunin, an anthocyanin in eggplant peels. Toxicology 148: 119-123.

O'Brien, M. 1983. Evaluation of eggplant accessions and cultivars for resistance to Verticillium wilt. Plant Disease Reporter 67: 763-764.

Picoli, E.A.T.; Otoni, W.C.; Figueira, M.L.; Carolino, S.M.B.; Almeida, R.S.; Silva, E.A.M.; Carvalho, C.R. \& Fontes, E.P.B. 2001. Hyperhydricity in in vitro eggplant regenerated plants: structural characteristics and involvement of BiP (Binding Protein). Plant Science 160(5): 857-868.

Prabhavathi, V.; Yadav, J.S.; Kumar, P.A. \& Rajam, M.V. 2002. Abiotic stress tolerance in transgenic eggplant (Solanum melongena L.) by introduction of bacterial mannitol phosphodehydrogenase gene. Molecular Breeding 9(2): 137-147.

Rao, P.V.L. \& Singh, B. 1991. Plantlet regeneration from encapsulated somatic embryos of hybrid Solanum melongena L. Plant Cell Reports 10: 7-11.

Rizza, F.; Mennella, G.; Collonnier, C.; Shiachakr, D.; Kashyap, V.; Rajam, M.V.; Prestera M. \& Rotino, G.L. 2002. Androgenic dihaploids from somatic hybrids between Solanum melongena and S. aethiopicum group gilo as a source of resistance to Fusarium oxysporum f. sp. melongenae. Plant Cell Reports 20(11): 1022-1032.

Rotino, G.L.; Falavigna, A. \& Restaino, F. 1987. In vitro selection of eggplant cells resistant to culture filtrate of Verticillium dahliae Kleb. And regeneration of plants. Capsicum Newsletter 6: 94-95.

Rotino, G.L.; Schiavi, M.; Vicini, E. \& Falavigna, A. 1991. Variation among androgenetic and embryogenetic lines of eggplant (Solanum melongena L.). Journal of Genetic Breeding 45: 141-146.

Rotino, G.L. \& Gleddie, S. 1990. Transformation of eggplant (Solanum melongena L.) using a binary Agrobacterium tumefaciens vectors. Plant Cell Reports 9: 26-29.

Sachetto-Martins, G.; Fernandes, L.D.; Felix, D. \& Oliveira, D. 1995. Preferential tramscriptional activity of a glycinerich protein gene from Arabidopsis thaliana in protoderm derived cells. International Journal of Plant Science 156: 460-470.

Sagare, A.P.; Suhasini, K. \& Krishnamurthy, K.V. 1995. Histology of somatic embryo initiation and development in chickpea (Cicer arietinum L.) Plant Science 109: 87-93.

Saito, T. \& Nishimura, S. 1994. Improved culture conditions for somatic embryogenesis using an asseptic ventilative filter in eggplant (Sollanum melongena L.). Plant Science 102: 205-211.

Saxena, P.K.; Gill, R.; Rashid, A. \& Maheshwari, S.C. 1981. Plantlet formation from isolate protoplasts of Solanum melongena L. Protoplasma 106: 355-359.

Scoccianti, V.; Sgarbi, E.; Fraternale, D. \& Biondi, S. 2000. Organogenesis from Solanum melongena L. (eggplant) cotyledon explants is associated with hormonemodulated enhancement of polyamine biosynthesis and conjugation. Protoplasma 211: 51-63. 
Sharma, P. \& Rajam, M.V. 1995a. Genotype, explant and position effects on organogenesis and embryogenesis in eggplant (Solanum melongena). Journal of Experimental Botany 46: 13-141.

Sharma, P. \& Rajam, M.V. 1995b. Spatial and temporal changes in endogenous polyamine levels associated with somatic embryogenesis from different hypocotyl segments of eggplant (Solanum melongena L.). Journal of Plant Physiology 146: 658-664.

Sharma, P.; Yadav, J.S. \& Rajam, V. 1997. Induction of lateral in root cultures of eggplant (Solanum melongena L.) in hormone-free liquid medium: A novel system to study the role of polyamines. Plant Science 125: 103-111.

Silva, M.E.; Santos, R.C.; O’Leary, M.C. \& Santos, R.S. 1999. Effect of aubergine (Solanum melongena) on serum and hepatic cholesterol and triglycerides in rats. Brazilian Archives of Biology and Technology 42(3): 339-342.

Tarré, E.; Magioli, C.; Margis-Pinheiro, M.; SachettoMartins, G.; Mansur, E. \& Fernandes, L.D. 2004. Somatic embryogenesis and adventitious root initiation have a common origin in eggplant (Solanum melongena L.). Revista Brasileira de Botânica 27(1): 70-84.

Tuberosa, R.; Sanghineti, M.C. \& Conti, S. 1987. Anther culture of eggplant Solanum melongena L. lines and hybrids. Genética Agrária 41(3): 267-274.
Yadav, J.S. \& Rajam, M.V. 1997. Spatial distribution of free and conjugated polyamines in leaves of Solanum melongena L. associated with differential morphogenetic capacity: efficient somatic embryogenesis with putrescine. Journal of Experimental Botany 48(313): 1537-1545.

Yadav, J.S. \& Rajam, M.V. 1998. Temporal regulation of somatic embryogenesis by adjusting cellular polyamine content in eggplant. Plant Physiology 116: 617-625.

Yamada, T.; Nakagawa, H. \& Sinoto, Y. 1967. Studies on the differentiation in cultured cells. I-Embryogenesis in three strains of Solanum callus. Botanical Magazine-Tokyo 80: $68-74$.

Yoshikawa, K.; Inagaki, K.; Terashita, T.; Shishiyama, J.; Kuo, S. \& Shankel, D.M. 1996a. Antimutagenic activity of extracts from Japanese eggplant. Mutation ResearchGenetic Toxicology 371(1-2): 65-71.

Yoshikawa, K.; Inagaki, K.; Terashita, T.; Shishiyama, J. \& Shankel, D.M. 1996b. Desmutagenic effect of pheophytin from Japanese eggplant against several mutagens. Journal of the Food Hygienic Society of Japan 37(5): 295-30. 